\title{
Land Suitability Evaluation Using a GIS-Based Logic Scoring of Preference Method
}

\author{
R M Masri \\ \{rinamasri@upi.edu\} \\ Civil Engineering Department, Universitas Pendidikan Indonesia
}

\begin{abstract}
The purpose of the research is creating geographic information system based logic scoring of the preferred method for housing land suitability evaluation, designing a digital database management system for housing land suitability evaluation, and producing the housing zone of land suitability evaluation. The research was conducted in Karawang from January 2019 to July 2019. The research is using descriptive method with the physical, environmental, socio-economic and conditions population data. The sampling technique is purposive. Primary data were taken by the chemical physical, and socio-economic and biological environment. Secondary data taken are maps of soil texture, erosion, flooding, slope, soil drainage, effective depth of soil and soil type. Spatial analysis using GIS software is used to superimpose layers. The thematic map which was producing the housing zone of land suitability evaluation from GIS software, satellite imagery from the internet produces a reasonable results compared with conventional and analog methods.
\end{abstract}

Keywords: Land suitability evaluation, Logic scoring, Database management system

\section{Introduction}

The land suitability analysis uses Cell-based Multi-criteria Evaluation (MCE) methods. The suitability of land estimation carries out a land evaluation for a specific use such as arable farming or irrigated agriculture. Fuzzy quantifiers incorporation into GIS-base land suitability analysis advantage by ordered weighted averaging (OWA) becomes the goal of study. A multi-criteria evaluation procedure or combination operator is done by OWA. Fuzzy quantifiers determine some parameters of the OWA procedure nature [1]. Bojorquez-Tapia, et al. [2] presented land suitability assessment using a GIS-based multivariate application with a public participation in Mexico [2]. Complex decisions within a short period of time which must take into account sustainable development and economic competitiveness are often made by land-use planners [3, 4]. Moreover, an introduction to GIS can be found in [5, $6,7,8]$.

Meng, Malczewski and Boroushaki [9] presented multi-criteria decision analysis approach based on a Geographic Information System for mapping housing development sites accessibility patterns. Multi-criteria decision analysis approach involved incorporating the linguistic quantifier concept as a method for obtaining the order weights and integrating two multi-criteria decision methods (Ordered Weighted Averaging and Analytical Hierarchy Process) in a raster GIS environment. 
Masri and Purwaamijaya [10] presented multi-criteria evaluation for regional function based on geographic information system. A conceptual, functional model and implementation resulted protected forest area, limited production forest area, permanent production forest area geometric information (centroid, perimeter and area). Standard operational procedure made a regional function using geographic information system multi-criteria evaluation consists of data input land slope, soil type, rainfall, and data out regional function rating, weight, a score (permanent production forest area, limited production forest area, protected forest area). Overlayed rainfall, soil and slope layers to gain regional function using multicriteria evaluation produced protected forest area and permanent production forest area smaller than limited production forest area. Researchers produced multi-criteria evaluation method which consisted of thematic map of rainfall, soil type and land slope which could be describing the rank of each theme on cheaper, faster and easier than conventional method. Researchers produced regional function table is a data structure rainfall, soil type and land slope combination automatically $[10,11,12]$.

The Logic Scoring of Preference (LSP) method is the computer system evaluation papers and the description of the an multi-criteria method that intoduced in the early 1970s. The LSP method the mathematical foundation is based on generalized conjuction/disjunction the soft computing concepts. Nonlinear is the LSP method the main advantage in the consistency with human evaluation reasoning observable properties [13].

\section{Methods}

The survey method was used for observing housing development base on GPS receiver in the real world, the documentary method was used for collecting land use, topographic, soil texture, administration and regional spatial arrangement plan maps.

The survey method goes through stages, namely: (1) creating textual data instrument, (2) making survey license, (3) preparing finance and schedule, (4) go to survey locations, (5) taking notes and pictures in survey locations, (6) making a resume.

The documentary method go through stages, namely: (1) creating conceptual model for determining base map resource and resolution, (2) creating data instrument (3) collecting base map and statistical data, (3) classifying data, based on data type and resolution or scale, (4) digitizing base map and thematic maps, (5) creating attribute data structure, (5) inputting attribute data and connecting textual data with graphical data through a unique identifier, (6) creating digital thematic maps, (7) doing spatial analysis, (8) printing results map.

\section{Results and Discussion}

\subsection{Model and Implementation of Land Suitability Evaluation for Housing}

The conceptual model presents the linkage between the resulting features and the users and resolution (see Table 1). There are 10 features consisting of a village, sub-district, district, land slope, soil effective depth, soil drainage, soil texture, erosion, soil type and rock type. The resolution or scale field is consisting of the small, medium and big map. The users are consisting of land and building tax office, agrarian office, public works office and 
environmental office. The conceptual model is used for determining the resolution / scale of the base map and institution resource.

Table 1. Conceptual model of land suitability evaluation for housing.

\begin{tabular}{|c|c|c|c|c|c|c|c|c|}
\hline \multirow[t]{2}{*}{ No. } & \multirow{2}{*}{$\begin{array}{l}\text { Spatial } \\
\text { information } \\
\text { (features) }\end{array}$} & \multicolumn{3}{|c|}{ Resolution / Scale } & \multicolumn{4}{|c|}{ Users } \\
\hline & & Small & Medium & $\overline{B i g}$ & $\begin{array}{c}\text { Land and } \\
\text { Building } \\
\text { Tax } \\
\text { Office }\end{array}$ & $\begin{array}{c}\text { Agrarian } \\
\text { Office }\end{array}$ & $\begin{array}{l}\text { Public } \\
\text { Works } \\
\text { Office }\end{array}$ & $\begin{array}{c}\text { Environmental } \\
\text { Office }\end{array}$ \\
\hline 1. & Village & - & $\mathrm{v}$ & $\mathrm{V}$ & $\mathrm{V}$ & $\mathrm{v}$ & $\overline{\mathrm{v}}$ & $\overline{\mathrm{v}}$ \\
\hline 2. & Sub-district & - & $\mathrm{v}$ & V & V & $\mathrm{v}$ & $\mathrm{v}$ & $\mathrm{v}$ \\
\hline 3. & District & $\mathrm{v}$ & $\mathrm{v}$ & V & V & $\mathrm{v}$ & $\mathrm{v}$ & $\mathrm{v}$ \\
\hline 4. & Land slope & $\mathrm{v}$ & $\mathrm{v}$ & - & - & $\mathrm{v}$ & $\mathrm{v}$ & $\mathrm{v}$ \\
\hline 5. & $\begin{array}{c}\text { Soil effective } \\
\text { depth }\end{array}$ & - & $\mathrm{v}$ & - & - & $\mathrm{v}$ & - & $\mathrm{v}$ \\
\hline 6. & Soil drainage & - & $\mathrm{v}$ & - & - & $\mathrm{v}$ & - & $\mathrm{v}$ \\
\hline 7. & Soil texture & - & $\mathrm{v}$ & - & - & $\mathrm{v}$ & - & $\mathrm{v}$ \\
\hline 8. & Erosion & $\mathrm{v}$ & $\mathrm{v}$ & - & - & $\mathrm{v}$ & $\mathrm{v}$ & $\mathrm{v}$ \\
\hline 9. & Soil type & $\mathrm{v}$ & $\mathrm{v}$ & - & - & $\mathrm{v}$ & $\mathrm{v}$ & $\mathrm{v}$ \\
\hline 10. & Rock type & $\mathrm{v}$ & $\mathrm{v}$ & - & - & $\mathrm{v}$ & $\mathrm{v}$ & $\mathrm{v}$ \\
\hline & Total & 5 & 10 & 3 & 3 & 10 & 7 & 10 \\
\hline
\end{tabular}

The functional model presents the relationship between the resulting feature and graphical information entity (see Table 2). There are 10 features consisting of a village, sub-district, district, land slope, soil effective depth, soil drainage, soil texture, erosion, soil type and rock type. The graphical information entity field is consisting of point, line, polygon and annotation.

Table 2. Functional model of land suitability evaluation for housing.

\begin{tabular}{|c|c|c|c|c|c|}
\hline \multirow[t]{2}{*}{ No. } & \multicolumn{5}{|c|}{ Graphical Information Entity } \\
\hline & $\begin{array}{c}\text { Spatial } \\
\text { information } \\
\text { (features) }\end{array}$ & Point & Line & Polygon & Annotation \\
\hline 1. & Village & $\mathrm{v}$ & - & $\mathrm{v}$ & $\mathrm{v}$ \\
\hline 2. & Sub-district & $\mathrm{v}$ & - & $\mathrm{v}$ & $\mathrm{v}$ \\
\hline 3. & District & $\mathrm{v}$ & - & $\mathrm{v}$ & $\mathrm{v}$ \\
\hline 4. & Land slope & $\mathrm{v}$ & - & $\mathrm{v}$ & $\mathrm{v}$ \\
\hline 5. & $\begin{array}{l}\text { Soil effective } \\
\text { depth }\end{array}$ & $\mathrm{v}$ & - & $\mathrm{v}$ & $\mathrm{v}$ \\
\hline 6. & Soil drainage & $\mathrm{v}$ & - & $\mathrm{v}$ & $\mathrm{v}$ \\
\hline 7. & Soil texture & $\mathrm{v}$ & - & $\mathrm{v}$ & $\mathrm{v}$ \\
\hline 8. & Erosion & $\mathrm{v}$ & - & $\mathrm{v}$ & $\mathrm{v}$ \\
\hline 9. & Soil type & $\mathrm{v}$ & - & $\mathrm{v}$ & $\mathrm{V}$ \\
\hline 10. & Rock type & $\mathrm{v}$ & - & $\mathrm{v}$ & $\mathrm{v}$ \\
\hline & Total & 10 & 0 & 10 & 10 \\
\hline
\end{tabular}

Implementation of land suitability evaluation for housing contains 4 phases (see Table 3 ), that are (1) base map digitization, (2) thematic map digitization and attribute input, (3) spatial analysis, (4) hardcopy. All phases were done using ArcGIS software. 
Table 3. Implementation of Land Suitability Evaluation for Housing.

\begin{tabular}{|c|c|c|c|c|}
\hline No. & Activity & Input data & Output data & Software \\
\hline 1. & Base map digitization & $\begin{array}{l}\text { Base map } \\
\text { Village } \\
\text { Sub-district } \\
\text { District } \\
\end{array}$ & Digital base map & ArcGIS \\
\hline 2. & $\begin{array}{l}\text { Thematic map digitization } \\
\text { and attribute input }\end{array}$ & $\begin{array}{c}\text { Land slope } \\
\text { Soil effective depth } \\
\text { Soil drainage } \\
\text { Soil texture } \\
\text { Erosion } \\
\text { Soil type } \\
\text { Rock type } \\
\end{array}$ & $\begin{array}{l}\text { Thematic maps and } \\
\text { textual tables }\end{array}$ & ArcGIS \\
\hline 3. & Spatial analysis & $\begin{array}{c}\text { Land slope } \\
\text { Soil effective depth } \\
\text { Soil drainage } \\
\text { Soil texture } \\
\text { Erosion } \\
\text { Soil type } \\
\text { Rock type } \\
\end{array}$ & $\begin{array}{l}\text { Housing land suitability } \\
\text { zone digital map }\end{array}$ & ArcGIS \\
\hline 4. & Hardcopy & $\begin{array}{c}\text { Housing land suitability zone } \\
\text { digital map }\end{array}$ & $\begin{array}{c}\text { Housing land suitability } \\
\text { zone analog map }\end{array}$ & ArcGIS \\
\hline
\end{tabular}

\subsection{Digital Thematic Maps of Land Slope, Soil Effective Depth, Soil Drainage, Soil Texture, Erosion, Soil Type, Rock Type}

Digital thematic map of land slope can be seen in Figure 1.a contains 1 layer with 5 records, that are (1) rather steep, (2) steep, (3) flat, (4) sloping, and (5) very steep.Digital thematic map of soil effective depth as can be seen in Figure 1.bcontains 1 layer with 4 records, that are (1) very shallow, (2) shallow, (3) medium, and (4) deep.Digital thematic map of soil drainage as can be seen in Figure 1.c contains 1 layer with 5 records, that are (1) productive aquifer with wide distribution, (2) high productive aquifer with wide distribution, (3) high to moderate productive aquifer, (4) rare groundwater area, and (5) local small productive aquifer means. The digital thematic map of soil texture as can be seen in Figure 1.d contains 1 layer with 3 records, that are (1) smooth, (2) medium, and (3) rough.

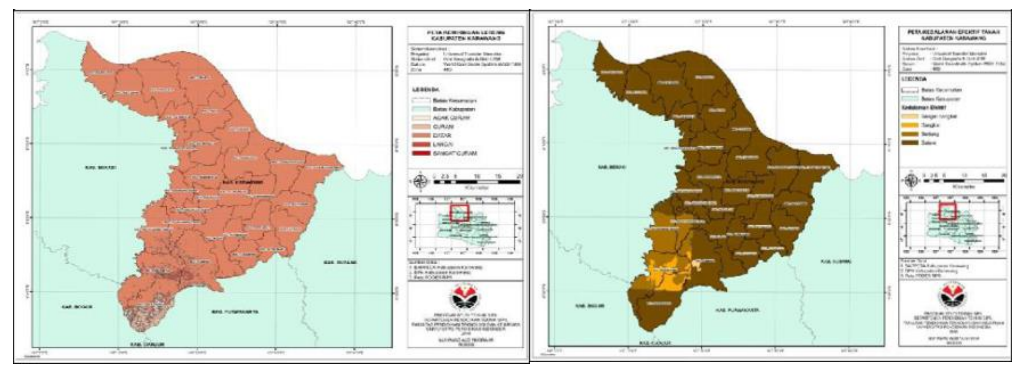

(a)

(b) 


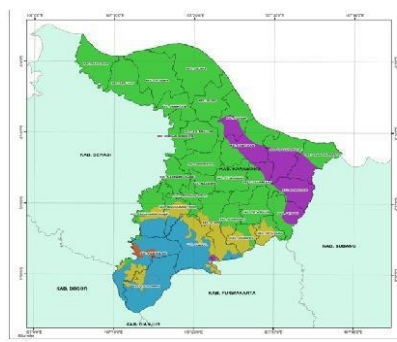

(c)

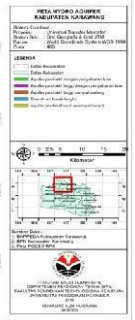

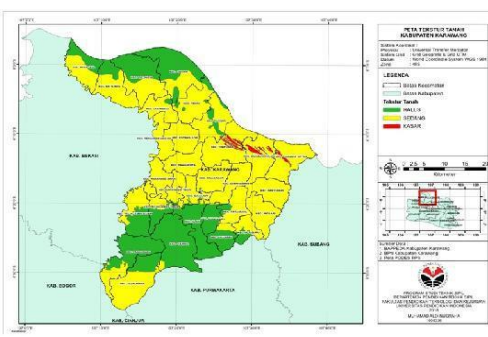

(d)

Fig. 1. Map of:a) Land Slope, b) Soil Effective Depth, c) Soil Drainage, and d) Soil Texture of Karawang District.

Digital thematic map of soil erosion as can be seen in Figure 2.a contains 1 layer with 4 records, that are (1) very low, (2) low, (3) middle class, and (4) high.Digital thematic maps of soil type as can be seen in Figure 2.b contains 1 layer with 5 records, that are (1) regosol, (2) podsol red yellow, (3) latosol, (4) grumosol, and (5) glei.Digital thematic map of rock type as can be seen in Figure 2.c contains 1 layer with 8 records, that are (1) alluvial and quarter deposits, (2) gamping quarter, (3) neogenous limestone, (4) quarter volcano rocks, (5) neogene sedimentary rocks, (6) origo-miocene sedimentary rocks, (7) pso-plistocene sedimentary rocks, and (8) neogene breakthrough rock.

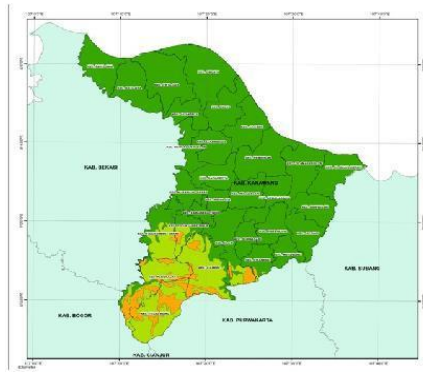

(a)

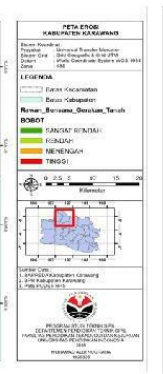

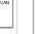

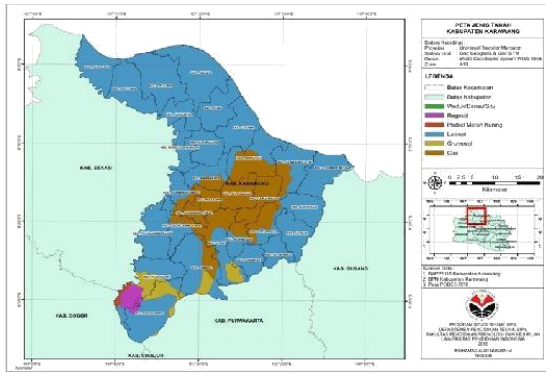

(b)

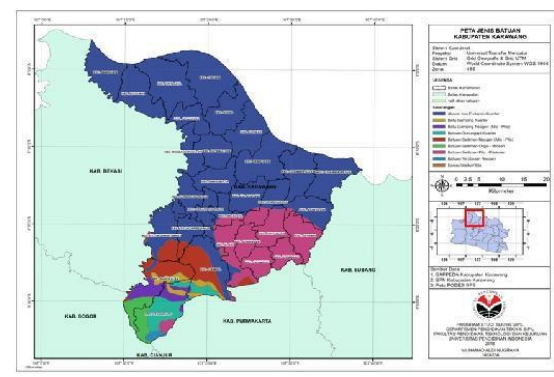

(c)

Fig. 2. Map of: a) Soil Erosion, b) Soil Type, and c) Rock Type of Karawang District. 


\subsection{Digital Map of Land Suitability Evaluation for Housing}

Digital map of land suitability evaluation for housing as can be seen in Figure 3 contain 11 layers, that are (1) land slope, (2) soil effective depth, (3) soil drainage, (4) soil texture, (5) erosion, (6) soil type, (7) rock type, (8) village, (9) sub-district, (10) district, and (11) housing land suitability zone map. 48 zone UTM coordinates tied all layers. Affine method which transformed the geodetic base map to UTM was used for the coordinate transformation.

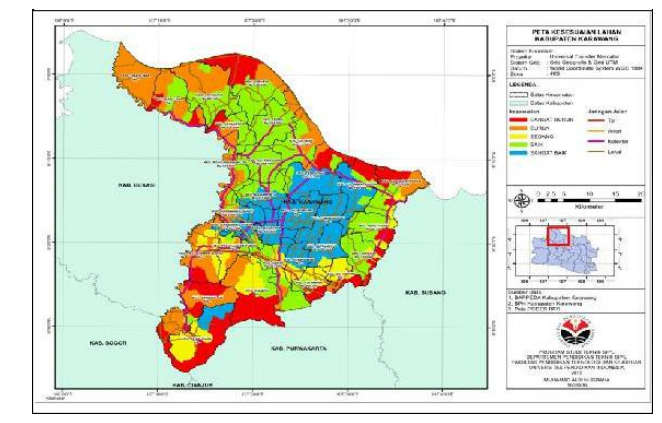

Fig. 3. Map of Land Suitability Evaluation for Housing.

\section{Conclusion}

The final result of this land suitability analysis is the representation of the map, namely the Land Suitability Map for Housing in Karawang District with a scale of 1: 300,000. There are five zones of land suitability for Housing in Karawang Regency. Land with "Very Bad" suitability of $25,199.055$ ha (16\%), land with a "Bad" suitability of 39,217.7 ha (25\%), land with suitability "Medium" of 19,615.08 ha (13\%), land with suitability "Good" amounted to 49,097.53 ha (31\%), land with "Very Good" suitability of 23,900.09 ha (15\%).

Some areas of Karawang District are in the "Good" suitability zone. The location identified can be seen in the Land Suitability Map for Housing in Karawang District.Based on Karawang District, the highest NJOP land value is West Karawang District with a land value of Rp. 2,004,000/m $\mathrm{m}^{2}$ which is dominated by the area included in the criteria of "Bad" zone for residential land use. While for land values based on NJOP the lowest is Tirta Mulya District with a land value of Rp. $80,100 / \mathrm{m}^{2}$ which is dominated by the area included in the criteria of "Very Good" zone for residential land use. This land value is dominated by Kertawaluya Village, with the dominating characteristics of land use being agriculture.

Acknowledgments. The author is grateful to Directorate General of Research and Development Strengthening, Rector of Universitas Pendidikan Indonesia, Dean of Faculty of Technology and Vocational Education, Head of Civil Engineering Education Department Universitas Pendidikan Indonesia for allowing research activities, validating result and moral support. 


\section{References}

[1] Mokarram M, and Aminzadeh F: A GIS-Based Multicriteria land suitability evaluationusing Ordered Weight Averaging with Fuzzy Quantifier : A Case Study in Shavur Plain, Iran The International Archives of the Photogrammetry, Remote Sensing and Spatial Information Sciences ResearchGate 38 II 508-512 (2010)

[2] Bojorquez-Tapia L A, Diaz-Mondragon S, and Ezcurra E: GIS-based approach forparticipatory decision making and land suitability assessment International Journal ofGeographical Information Science Taylor and Francis 152 129-151 (2001)

[3] Joerin F, Theriault M, and Musy A: Using GIS and outranking multicriteria analysis forland-use suitability assessment International Journal of Geographical Information ScienceTaylor and Francis 152 153-174 (2001)

[4] Dujmovic J, and De Tre G: Multicriteria Methods and Logic Aggregation in SuitabilityMaps International Journal of Intelligent Systems Wiley Periodicals 26 971-1001 (2011)

[5] Malckzewski J: GIS-based land-use suitability analysis : a critical overview Progress in Planning Elsevier 62 3-65 (2004)

[6] Memarbashi E, Azadi H, Barati A A, Mohajeri F, Van Passel S, and Witlox F: LandUseSuitability in Northeast Iran : Application of AHP-GIS Hybrid Model ISPRS InternationalJournal of Geo-Information MDPI 6396 1-15 (2017)

[7] Feizizadeh B, Roodposthi M S, Jankowski P, and Blaschke T: A GIS-based extended fuzzymulticriteria evaluation for landslide susceptibility mapping Computer and GeosciencesElsevier 732014 208-221 (2014)

[8] Al-Shalabi M A, Mansor S B, Ahmed N B, and Shiriff R: GIS Based MulticriteriaApproaches to Housing Site Suitability Assessment Shaping the Change XXIII FIG CongressMunich Germany October 8-13 2006 1-17 (2006)

[9] Meng Y, Malczewski J, and Boroushaki S: A GIS-Based Multicriteria Decision AnalysisApproach for Mapping Accessibility Patterns of Housing Development Sites : A Case Study in Canmore, Alberta Journal of Geographic Information System Scientific Research 3 50-61 (2010)

[10] Masri R M and Purwaamijaya I M: Multi Criteria Evaluation for Regional Function Basedon Geographic Information System Proceeding - 2017 3rd International Conference onScience in Information Technology: Theory and Application of IT for Education, Industry and Society in Big Data Era, ICSI Tech 2017 Research Gate 1-5 (2018)

[11] Purwaamijaya I M: Multi criteria evaluation for universal soil loss equation based ongeographic information system Journal of Physics : Conference Series IOP Publishing 1013 (2018)012153 17(2018)

[12] Masri R M: Environmental management and monitoring for education building development Journal of Physics : Conference Seris IOP Publishing 1013 (2018)012105 1-8 (2018)

[13] Montgomery B, Dragic'evic S, Dujmovic J, and Schmidt M: A GIS-based Logic ScoringPreference method for evaluation of land capability and suitability for agriculture Computersand Electronics in Agriculture Elsevier 124(2016) 340-353 (2016) 